\title{
Environmental justification of legal consequences of illegal actions in the Russian Federation
}

\author{
Olga Ilyina ${ }^{1}$, Anatoly Levushkin ${ }^{2, *}$, and Julia Dronova $^{1}$ \\ ${ }^{1}$ Tver State University, 33, Zhelyabova str., 170100, Tver, Russia \\ ${ }^{2}$ Ulyanovsk state University, 40/9 Goncharova str., 432970, Ulyanovsk, Russia
}

\begin{abstract}
The issue of alimony obligations enforcement is quite acute in our country. It is necessary to recognize that Russian legislation does not contain effective mechanisms for collecting funds from parents for the maintenance of minor children. The article reveals the legal nature of consequences of non-payment of funds for the maintenance of minor children by their parents from the point of view of ratio of private and public interests in the mechanism of legal regulation. The authors note the prerequisites and limits of shifting the balance of private and public interests in the study of grounds for applying criminal liability measures for non-payment of alimony.
\end{abstract}

\section{Introduction}

In accordance with Article 80 of Family Code of Russian Federation, parents are obliged to support their minor children, which fully meets their natural function of providing the conditions necessary for normal physical, mental, spiritual and moral development of a child. Alimony (alimentum from Lat. - "food"), as a rule, is associated with a certain amount of money paid or subject to recovery for the maintenance of a child, although modern law enforcement practice indicates the spread of other forms of "nutrition", that is, meeting the needs of a child. This can be the provision of real estate, payment for summer vacations and educational courses, direct purchase of clothing, office supplies, etc.

Determination of legal consequences of non-payment of alimony for minor children from the point of view of civil law and criminal law aspects is currently one of the most controversial and fundamental issues of importance for law enforcement.

Legislators rightly proceed from the presumption of parents' good faith in maintaining minor children, since collection of funds as alimony in court occurs if parents do not provide maintenance to their children (Clause 2, Article 80 of Family Code). By virtue of dispositive norms, the obligation of parents to support children can be exposed in the form of an agreement on the payment of alimony, conditions and form of which must comply with the rules of Chapter 16 of Family Code.

\footnotetext{
*Corresponding author: lewuskin@mail.ru
} 
Thus, the state provides parents with the opportunity, at their discretion and taking into account the interests of children, to use the contractual structure within the framework of alimony obligation provided by public law guarantees. Moreover, these guarantees are very clearly traced in the relevant articles of Family Code. In particular, the amount of alimony established for minor children in an agreement on the payment of alimony cannot be lower than the amount that children could receive when collecting alimony in court (clause 2 of article 103 of Family Code); if this rule is not observed, the agreement may be invalidated as violating the interests of a child (Article 102 of Family Code).

Statistical data provided by the Federal Bailiff Service on parents who evade paying alimony for their minor children are fairly stable. In this connection, the issue of applying liability measures to parents in case of non-payment of funds for the maintenance of minor children remains relevant. According to the data of the Main Information and Analytical Center of Ministry of Internal Affairs of Russian Federation, the registered number of crimes provided for by Article 157 of Criminal Code of Russian Federation (hereinafter Criminal Code) "Failure to pay funds for the maintenance of children or disabled parents" in January-December 2017 amounted to 54,759 (98,7\%), for January-December 2018 $52,044(-5.0 \%)$, for January-December 2019 - 51,516 (-1.0\%), for January-October 2020 $37069(-18.0 \%)$ [1]. These figures indicate a tendency towards a decrease in the number of registered crimes provided for by Article 157 of Criminal Code. However, it must be understood that since mid-2016, statistics of commission of administrative offenses provided for in 5.35.1 of Code of Administrative Offenses of Russian Federation (hereinafter referred to as Code of Administrative Offenses) began to form. And in this light, changes in the number of registered crimes provided for by Article 157 of Criminal Code no longer look so rosy and significant.

\section{Methods}

The methodological basis of this scientific research was made by general scientific methods of cognition of legal phenomena, such as synthesis, method of analogy, formal logic and others, as well as particular scientific methods of researching an intersectoral approach to the legal regulation of consequences of non-payment of alimony for minor children.

Comparative and sociological methods of scientific knowledge were also used [2].

It is necessary to understand that scientific understanding of legal consequences of nonpayment of alimony for minor children from the point of view of a civilistic and criminallegal approach is possible, provided there is a set of methods for resolving possible conflicts and conscientious behavior of participants in the framework of family legal relations. At the same time, recently, in connection with development of market and information sphere, possibilities of abuse of rights, including family rights, have expanded enough, which requires prompt development of measures to protect the recipients of alimony in alimony obligations.

\section{Results}

In 2016, significant changes were made to the mechanism of criminal liability for failure to provide funds for the maintenance of children and parents, which resulted in the establishment of additional measures of public legal liability for failure to fulfill so-called alimony obligation. Previous version of Art. 157 of Criminal Code of Russian Federation provided for liability only in case of malicious evasion from payment of funds by a court decision. Thus, if a parent did not fulfill the terms of agreement on the payment of alimony for a child, he/she could not be subjected to measures of criminal liability. 
An analysis of provisions of civil, family and criminal legislation allows us to assert the obvious priority of private interests when the subjects of family legal relations use contractual structures. As evidenced by the materials of law enforcement practice, a significant part of parents' agreements are certified by a notary by virtue of a direct requirement of law or at the request of parents.

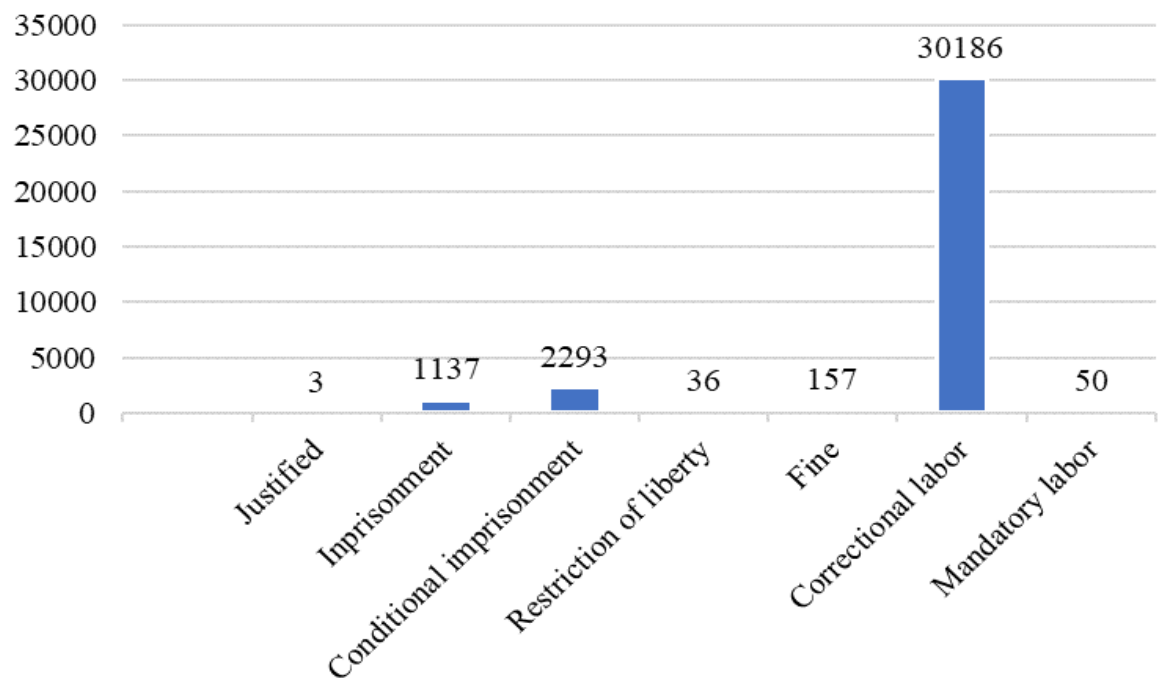

Fig. 1. Statistics on criminal cases initiated under Part 1 of Article 157 of Criminal Code of Russian Federation, 2018.

As part of dispositive regulation of alimony obligations, it is possible to conclude an agreement on the payment of alimony, which can be changed or terminated at any time by mutual agreement of parties (Article 101 of Family Code), in this connection, it would be strange to apply criminal sanctions for failure to comply with conditions contracts determined solely by the will of parties.

At the same time, legislators restrict the will of parties to the agreement by an imperative prescription on the minimum amount of funds paid for the maintenance of a child under an agreement on the payment of alimony. Conditions that do not comply with this rule, and other conditions for providing maintenance to a child that violate the interests of the latter, may become the basis for a court to declare an agreement on the payment of alimony invalid (Article 102 of Family Code).

The principles of resolving intra-family issues by mutual consent, inadmissibility of arbitrary interference by anyone in the family affairs, provided for by family legislation, determine the prospects for regulating family relations with the advantage of private interests [3]. In the modern period, there has been a tendency for cross-sectoral relationships between family and other relationships.

It becomes obvious that the state demonstrates its interest in ensuring the rights and interests of a child when providing, under the terms of an agreement on the payment of alimony for his/her maintenance, money, the logical conclusion of which is the establishment of criminal liability for non-payment of funds on the basis of not only a judicial act, but also the corresponding agreement.

It should be noted that for a parent who does not fulfill obligations to provide maintenance to a minor child, various adverse personal non-property and property consequences may occur. 
First of all, we are talking about the possibility of paying not only current payments, but also the resulting debt (Article 113 of Family Code), forfeit (Article 115 of Family Code) and (or) indebtedness for the payment of the penalty (Article 114 of Family Code).

Malicious evasion of payment of alimony is still one of the grounds for depriving parents of parental rights (Article 69 of Family Code), but the parent is not exempt from the obligation to support the child.

The issue of liability for non-payment of alimony can also be traced in the sphere of hereditary legal relations. "At the request of an interested person, the court removes from inheritance according to the law citizens who maliciously evaded the fulfillment of their obligations to maintain the testator by virtue of law" (clause 1 of article 1117 of Civil Code of Russian Federation).

\section{Discussion}

There is no unity among representatives of science of family law regarding the advisability of establishing and the effectiveness of application of criminal liability of parents for failure to fulfill the obligation to pay alimony for children.

Earlier, one of the authors of this article expressed the opinion that the corresponding amendments to the criminal law fully correlate with the public-law nature of agreement on the payment of alimony: "We are talking about criminal liability for non-execution of a transaction with special legal force. An agreement on the payment of alimony, certified by a notary, has the force of a writ of execution. In this regard, it is necessary to consider measures of criminal liability as a consequence of non-execution of a writ of execution - a special document. The very fact that the subjects of family legal relations reach an agreement on the conditions and procedure for provision of alimony is, in fact, equated to the fact of establishing the appropriate order in a court decision "'[4].

The structure of a crime under discussion and corresponding sanctions are provided for in Article 157 of Criminal Code of Russian Federation "Failure to pay funds for the maintenance of children or disabled parents."

An agreement on payment of alimony for minor children is very attractive in terms of law enforcement and is more widespread precisely because the alimony payer can provide any property for maintenance, by the way, quite often the subject of agreement is the transfer of living quarters to the child's ownership.

However, article 157 of Criminal Code of Russian Federation provides for liability only for non-payment of funds for child support. Consequently, if the parent evades the execution of an agreement involving the transfer of any property, for example, the periodic acquisition of personal items, stationery and other items necessary for learning throughout the child's schooling, there are no grounds for applying criminal punishment.

Thus, a parent-payer under an agreement on payment of alimony can be brought to administrative (Article 5.35.1 of Code of Administrative Offenses of Russian Federation) and criminal liability only if the said agreement provides for payment of money as alimony as the only or one of the conditions for the maintenance of a child.

It should be noted that Russian Federation finances federal programs for protection and promotion of public health [5]. Failure to provide alimony for a child negatively affects the health of children. The position of Supreme Court of Russian Federation declares the need for a new view of alimony legal relations [6]. Thus, when considering case No. 45-KG 161, the judges of Collegium for Civil Cases of Supreme Court of Russian Federation considered that the arrears in the payment of alimony should be included in the estate. The rationale is as follows: a court ruling to collect alimony imposes on the citizen the obligation to pay a certain amount of money every month. If he does not do this, a debt arises, a monetary obligation that is no longer associated with the person of the debtor. 
Therefore, "the obligation to pay it passes to the heir of the debtor, which the latter, subject to his acceptance of inheritance, is obliged to pay off within the value of inherited property transferred to him," the Supreme Court of Russian Federation believes.

One should agree with the opinion of A.N. Levushkin, that "the measures of forcing the debtor to fulfill his obligations, introduced into the practice of enforcement agencies, are very effective" [7].

Article 157 of Criminal Code of Russian Federation in July 2016 was subjected to significant changes. The essence of changes was not only that legislators introduced liability for non-payment by a parent in violation of a notarized agreement (previously only evasion of payment by a court decision was criminalized) funds for the maintenance of minor children and disabled children who have reached 18 years.

Taking into account the main goal of bringing to justice non-payers of alimony (ensuring and protecting the property rights of a child), it seems significant that legislators establish as types of punishments for this offense those not involving property deprivation (only if it is impossible to apply compulsory work or arrest may be a fine is imposed). Thus, the introduction of an administrative prejudice to criminalize persons who do not pay alimony, on the one hand, partially decriminalized this act, on the other hand, provided the person correctly understands the consequences of further evasion from paying alimony after being brought to administrative responsibility for this, is intended to perform a preventive function and reduce the number of cases of non-payment requiring a criminal-legal response. Any conclusions regarding the achievement of these goals, obviously, can be drawn on the basis of an analysis of statistical data on this type of crime. Comparison of relevant data for the years preceding the introduction of changes in the Criminal Code and Administrative Code, 2014-2015 and the years following the year of introduction of changes, 2017-2019 (it is hardly advisable to take 2016 into account, since, firstly, changes were introduced in the middle of the year - in July, and, secondly, it takes some time to form law enforcement practice). It should be noted that the Federal Bailiff Service then supported the idea of decriminalizing liability for a crime provided for in Article 157 of Criminal Code, as it believed that this would improve judicial practice, allow one to get away from the evaluative concept and help prevent crimes [8].

\section{Conclusion}

We believe that, nevertheless, it is not possible to fully ensure the interests of a child in terms of receiving maintenance from parents who have entered into an agreement on the payment of alimony among themselves, when one of them is brought to criminal liability. And this is due to the specifics of the named agreement.

In accordance with article 104 of Family Code, the parties to the agreement can establish any methods and procedure for paying alimony: it can be a monetary amount paid in proportion to the shares of earnings or other income, in a lump sum or periodically, it can also be the provision of property. And, most importantly, the law allows a combination of different methods of paying child support.

An agreement on the payment of alimony is a very convenient tool for regulating relations for maintenance of a minor child, since not only from the outset it is possible to establish a mutually optimal option for providing funds and any property, but also if it becomes necessary to change the terms of agreement or terminate it. This is a very significant circumstance in comparison with the fulfillment of alimony obligation, formally confirmed by a judicial act: a decision or order.

In our opinion, the study of issue of expediency and validity of criminalization of nonpayment of funds for the maintenance of minor children should be carried out through the 
prism of relationship between private and public interests in the mechanism of legal regulation of family relations.

The above mentioned judgments demonstrate a complex mechanism for implementation of a high degree of care for minors, on the establishment of a system of institutions of various industries, the use of which in a complex aims to ensure the rights and interests of a child through the provision of content by the parents in the forms and procedure provided for by law.

It has been determined that bringing alimony defaulters to administrative responsibility does not achieve its preventive goal, and most of them continue their unlawful behavior during the period when a person is considered subject to administrative punishment, and therefore there are grounds for bringing them to criminal liability. Does this mean that legislators took the wrong steps in terms of changing the mechanism of public law response to evasion of payment of alimony? There are no grounds for such an unambiguous conclusion, but, at the same time, it should be recognized that this mechanism needs further improvement, the purpose of which, as already noted, is to ensure the rights and interests of children.

\section{References}

1. The official website of the GIAC of Ministry of Internal Affairs of Russian Federation, https: //mvd.rf/mvd/structure1/Centri/Glavnij_informacionno_analiticheskij_cen

2. I.V. Ershova, E.E. Enkova, A.N. Levushkin, K.K. Dzhindzholiya, Theory and Practice of Project Management in Education: Horizons and Risks. International Scientific and Practical Conference. SHS Web of Conferences 79, 1005 (2020) DOI: https://doi.org/10.1051/shsconf/20207901005

3. O.Yu. Ilyina, Family and housing law 1, 14 - 17 (2019)

4. O.Yu. Ilyina, Bulletin of the Tver State University. Series "Right" 3, 69-78 (2016)

5. A.A. Mokhov, A.N. Levushkin, A.N. Yavorsky, Journal of Advanced Research in Law and Economics XI- 2(48)-11(2), 483 - 490 (2020)

6. O.Yu. Ilyina, Socio-legal notebook 6, 47-57 (2016)

7. A.N. Levushkin Executive law 2, 17 - 21 (2011)

8. Federal Bailiff Service supported the mitigation of punishment for non-payment of alimony, https://rg.ru/2016/07/05/reg-pfo/fssp-podderzhala-dekriminalizaciiu-stati-uko-nevyplate-alimentov.html

9. V. Lez'Er, N. Semerianova, A. Kopytova, Y. Truntsevsky, E3S Web of Conferences 110, 02093 (2019) DOI: 10.1051/e3sconf/201911002093

10. A.V. Kopytova, N.S. Zotkina, I.G. Reshetnikova, MATEC Web of Conferences 239, 04012 (2018) DOI: 10.1051/matecconf/201823904012

11. R. Kolobov, U. Filatova, V. Borshcheniuk, N. Semerianova, D. Bayanov, E3S Web of Conferences 110, 02095 DOI: 10.1051/e3sconf/201911002095

12. Y.V. Truntsevsky, I.I. Lukiny, A.V. Sumachev, A.V. Kopytova, MATEC Web of Conferences 170, 01067 (2018) DOI: 10.1051/matecconf/201817001067

13. N. Semeryanova, O. Fedorenko, A. Kopytova, MATEC Web of Conferences 239, 04013 (2018DOI: 10.1051/matecconf/201823904013 